\title{
KNOCK DOWN BAMBOO WALL PANEL
}

\author{
${ }^{1}$ Vivi Yani Santosa. ${ }^{2}$ Anastasia Maurina, S.T., M.T. \\ ${ }^{1}$ Student in the Bachelor's (S-1) Study Program in Architecture \\ at Parahyangan Catholic University \\ ${ }^{2}$ Senior lecturer in the Bachelor's (S-1) Study Program in Architecture \\ at Parahyangan Catholic University
}

\begin{abstract}
Indonesia often experiences natural disasters, therefore a transitional residential building is needed for victims who are able to build quickly and easily in mobilization. Bamboo is a local material that exists in Indonesia and has a high sustainability to be used as building materials. The appropriate principle between the characteristics of bamboo and the needs of transitional buildings where used as wall materials. The knock down bamboo wall panel is the answer of the need for fast and easy work in mobilization.The research method used is qualitative descriptive of two study object and design experiment of prototype 1: 1. Researchers will conduct a study of bamboo walls on two study objects Blooming Bamboo Home dan Soe Ker Tie House, also meetings of any deficiencies and advantages from aspects of form, function and context, and construction. Forms include material used, basic dimensional modules, wall weight, and the ability to re-modify walls. Functions and Contexts include the space privacy, resistance, and behavior of walls against wind, solar heat, lighting, and rain. Construction covers the way of bamboo processing into wall panels, connection systems, and can be done massively by the crowd. Potential bamboo wall variants to be explored will be evaluated and developed for the better and new alternative of other wall panels also considered.The most efficient bamboo knock down panels are bamboo slats and woven bamboo booths as massive walls, woven bamboo and bamboo modified blades I as semiopen walls, modified bamboo blades II and polikarbonate as open walls. The most appropriate connection system used in knock down bamboo wall panels is the gypsum screw connection for bamboo wall panel frame joints, bolt nuts and iron plates for knock down bamboo wall panel connections with structures and connections between wall panels.
\end{abstract}

Keywords: Knock down, Bamboo, Sustainable, Wall panel

\section{PANEL DINDING BAMBU KNOCK DOWN}

\author{
${ }^{1}$ Vivi Yani Santosa. ${ }^{2}$ Anastasia Maurina, S.T., M.T. \\ ${ }^{1}$ Mahasiswi S1 Program Studi Arsitektur Universitas Katolik Parahyangan \\ ${ }^{2}$ Dosen Pembimbing S1 Program Studi Arsitektur Universitas Katolik Parahyangan
}

\begin{abstract}
Abstrak- Indonesia sering mengalami bencana alam, oleh karena itu dibutuhkan bangunan tempat tinggal transisional untuk para korban yang mampu dibangun dengan cepat dan mudah dalam mobilisasi. Bambu merupakan material lokal yang ada di Indonesia serta memiliki daya keberlanjutan tinggi sehingga berpotensi untuk dijadikan material bangunan. Prinsip yang sesuai antara karakteristik bambu dengan kebutuhan bangunan transisional memungkinkan bambu dijadikan material dinding. Panel dinding bambu knock down merupakan jawaban dari kebutuhan akan pengerjaan yang cepat dan mudah dalam mobilisasi.Metode penelitian yang digunakan adalah deskriptif kualitatif dari dua objek studi serta eksperimen desain dalam bentuk prototype 1:1. Peneliti akan melakukan kajian dinding bambu pada dua objek studi Blooming Bamboo Home dan Soe Ker Tie House, serta mengevaluasi setiap kekurangan dan kelebihan dari aspek bentuk, fungsi dan konteks, serta keteknikan. Bentuk meliputi material yang digunakan, modul dimensi dasar, berat dinding, dan kemampuan untuk dapat memodifikasi ulang dinding. Keteknikan meliputi cara pengolahan bambu menjadi panel dinding, sistem sambungan, dan mampu dikerjakan secara massal oleh orang banyak. Varian pengisi panel dinding bambu knock down yang paling efisien adalah bambu bilah vertikal dan anyaman bambu bilik sebagai dinding masif, anyaman bambu dan bambu bilah modifikasi I sebagai dinding semi terbuka, bambu bilah modifikasi II dan polikarbonat sebagai dinding terbuka. Sistem sambungan yang paling tepat digunakan pada panel dinding bambu knock down
\end{abstract}

\footnotetext{
${ }^{1}$ Corresponding Author: viviyanisantosa@gmail.com
} 
adalah sambungan sekrup gypsum untuk sambungan bingkai panel dinding bambu, mur baut dan plat besi untuk sambungan panel dinding bambu knock down dengan struktur dan sambungan antar panel dinding.

Kata kunci: Knock down, Bambu, Keberlanjutan, Panel dinding

\section{PENDAHULUAN}

Kebutuhan akan bangunan transisi semakin besar terutama ketika keadaan darurat seperti bencana. Menurut Perda Nomor 7 Tahun 2010 tentang Bangunan Gedung, bangunan semi permanen adalah bangunan yang digunakan untuk fungsi yang ditetapkan dengan konstruksi semi permanen atau yang dapat ditingkatkan menjadi permanen. Bangunan semi permanen menuntut pengonstruksian yang cepat, mudah dalam hal mobilisasi, dapat dibongkar pasang (knock down), dan sustainable.

Faktor kecepatan merupakan hal yang penting karena tujuan bangunan semi permanen adalah dapat dengan cepat menggantikan fungsi bangunan lain saat keadaan darurat. Saat bencana terjadi, dalam jumlah besar korban membutuhkan produksi massal bangunan semi permanen sehingga dibutuhkan pengerjaan dinding yang mudah dan cepat.

Bambu di Indonesia sering digunakan sebagai material bangunan karena kuat dan ketersediaannya di Indonesia sangat banyak. Oleh karena itu dipilih material bambu sebagai panel dinding dengan sistem knock down untuk mendukung produksi massa bangunan semi permanen.

Contoh bangunan dengan elemen dinding yang memenuhi pertimbangan faktor diatas adalah Blooming Bamboo Home di Vietnam, dan Soe Ker Tie House di Thailand. Kedua bangunan tersebut menggunakan material bambu sebagai elemen dinding bangunan.

Dengan observasi dan analisis mengenai bentuk dinding, sistem, dan sambungan pada objek penelitian maka akan ditemukan jenis-jenis panel dinding bambu yang dapat diaplikasikan dengan sistem knock down pada bangunan sementara, namun tidak menutup kemungkinan untuk dilakukan modifikasi desain panel dinding panel bambu yang mengakomodasi semua permasalahan teknis seperti sistem panel bambu atau besaran modul elemen dinding, sistem sambungan, kecepatan konstruksi, dan keberlanjutan (sustainable).

Hal yang dituntut dalam pembangunan bangunan semi permanen untuk para korban bencana adalah bangunan dengan membutuhkan elemen-elemen bangunan yang dapat cepat dibangun, sustainable, dan mudah dalam mobilisasi. Salah satunya adalah mengenai dinding bangunan. Dibutuhkan sistem dinding panel yang modular yang tidak memakan waktu pembuatan dan pemasangannya serta mudah untuk dimobilisasi ke lokasi bencana. Material yang digunakan diharapkan dapat tersedia dalam jumlah besar dan merupakan material lokal dengan durabilitas tinggi. Sambungan yang menyatukan panel dinding dengan struktur maupun sambungan antar elemen dinding menjadi hal yang perlu diperhatikan.

Dari rumusan permasalahan diatas, muncul sejumlah pertanyaan yakni (1) Apa saja kelebihan dan kekurangan panel dinding bambu pada objek studi? (2) Apa varian panel dinding bambu knock down yang efisien untuk digunakan? (3) Bagaimana sistem sambungan cara aplikasi panel dinding bambu knock down? Pertanyaan penelitian tersebut menghasilkan tujuan dari penelitian yang ingin dicapai, yakni mendapatkan bentukan panel dinding bambu dengan sistem knock down dengan sistem sambungan yang tepat sehingga mendukung kebutuhan produksi massal bangunan cepat konstruksi, mudah mobilisasi, dan sustainable.

Batasan pada penelitian ini berupa panel dinding bambu dengan sistem knock down. Material dibatasi pada bambu karena merupakan material lokal yang sustainable sehingga dapat memenuhi kebutuhan dalam jumlah banyak dan ramah lingkungan. Batasan variabel pembahasan panel dinding bambu knock down meliputi hal bentuk, fungsi, konteks, dan keteknikan. Bentuk membahas mengenai material yang digunakan, modul dimensi dasar panel dinding, dan berat dinding. Fungsi membahas privasi ruang sehingga dapat menjadi 
pertimbangan penggunaan panel dinding. Konteks lingkungan sekitar seperti angin, panas matahari, cahaya, dan air hujan juga memengaruhi penggunaan tipe panel dinding bambu. Ruang membahas pengisi dari panel dinding sedangkan teknik membahas mengenai durabilitas panel dinding bambu, cara pengolahan bambu menjadi panel dinding, dan sambungan sehingga panel dinding bambu knock down dapat dikonstruksikan.

Penelitian menggunakan metode deskriptif kualitatif dari dua objek studi serta eksperimen desain dalam bentuk prototype 1:1. Peneliti akan melakukan kajian dinding bambu pada dua objek studi Blooming Bamboo Home dan Soe Ker Tie House, serta mengevaluasi setiap kekurangan dan kelebihan dari aspek bentuk, fungsi dan konteks, serta keteknikan.

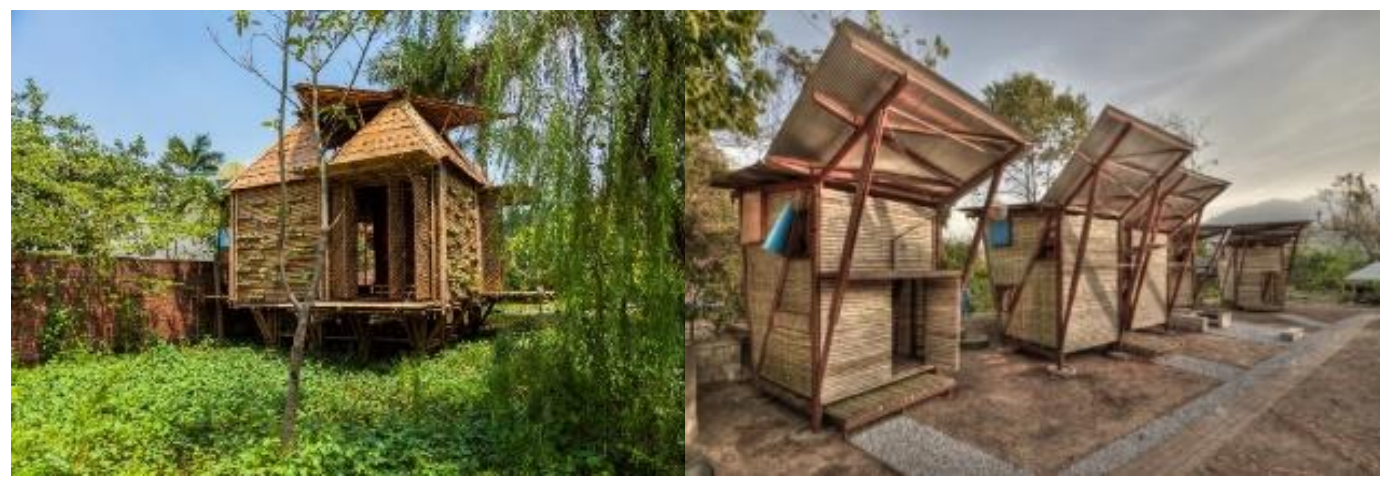

Figur 1. Objek Studi

(kiri) Blooming Bamboo Home, Vietnam. Dirancang oleh H\&R Architect. (kanan) Soe Ker Tie House, Thailand. Dirancang oleh TYN Architect. Sumber: www.dezeen.com, diakses 1 Februari 2017

\section{LANDASAN TEORI}

\subsection{UNSUR-UNSUR ARSITEKTUR (D.K.CHING, 2000)}

(1) Bentuk, dikenali secara visual (2) Fungsi, Tuntutan kebutuhan (3) Konteks, mencakup iklim (angin, matahari, temperatur, hujan) dan faktor budaya (4) Teknik meliputi sistem struktur, kekuatan pelingkup, maintenance, daya tahan (5) Ruang, volume yang terlingkupi, terbentuk, dan terorganisir maupun terisi oleh unsur-unsur massa.

\subsection{ARCHITECTURE DESIGN VALUES (LERA S.G, 1980)}

(1) Environmental Design Values (2) The Economic Design Values (3) Social Design Values (4) Aesthetic Design Values.

\subsection{BAMBU SEBAGAI MATERIAL DINDING (HEINZ FRICK, $2004 \&$ BAMBOO AS A SUSTAINABLE MATERIAL, THESIS REPORT)}

(1) Macam dinding bambu. Bambu utuh/ setengah, bambu bilah/ bambu rata, bajareque, dan wattle bamboo/ anyaman Bambu. (2) Jenis bambu Indonesia (3) Bambu Tali/ apus, bambu petung, bambu duri/ori, bambu wulung/ hitam. Memengaruhi dimensi, berat, dan karakteristik bamboo. (4) Pengolahan bentuk bambu (Heinz Frick). Bilah bambu, tutu, bambu lapis, tali bambu, melengkungkan bamboo.

\subsection{PREFABRIKASI (SIRADJUDDIN, 1993)}

(1) Pengulangan dan jumlah komponen. (2) Fungsi dan ukuran, dapat digunakan untuk berbagai fungsi, ukuran bervariatif. 


\subsection{KNOCK DOWN (ASTUTIEK, 2006)}

(1) Moduler (2) Sistem perulangan (3) Struktur (4) Sambungan

\subsection{TINJAUAN PUSTAKA}

Simpulan dari tinjauan pustaka yang digunakan adalah adanya 3 hal aspek yang dilihat dalam panel dinding knock down, yaitu: (1) Bentuk. Bentuk meliputi aspek material apa saja yang digunakan dan jumlah material. Jumlah material ditentukan oleh besaran modul dasar. Dari jumlah material yang digunakan untuk membuat modul dasar akan diperoleh berat dinding. (2) Fungsi dan Konteks. Fungsi meliputi privasi ruang yang berbeda-beda sesuai dengan kegunaan ruang tersebut. Konteks meliputi hal respon dinding terhadap angin, panas matahari, pencahayaan, dan hujan. Konteks ini juga berkaitan dengan fungsi ruang didalamnya. (3) Keteknikan. Hal keteknikan ini meliputi durabilitas dinding, cara pengolahan bambu menjadi dinding, sistem sambungan yang digunakan, sistem penggunaan dinding kembali, dan sambungan panel dinding bambu knock down ke struktur bangunan.

\section{KAJIAN APLIKASI PANEL DINDING BAMBU PADA OBJEK STUDI}

\subsection{DINDING PADA BLOOMING BAMBOO HOME}

Tabel 1. Dinding Bambu Utuh Horizontal Blooming Bamboo Home

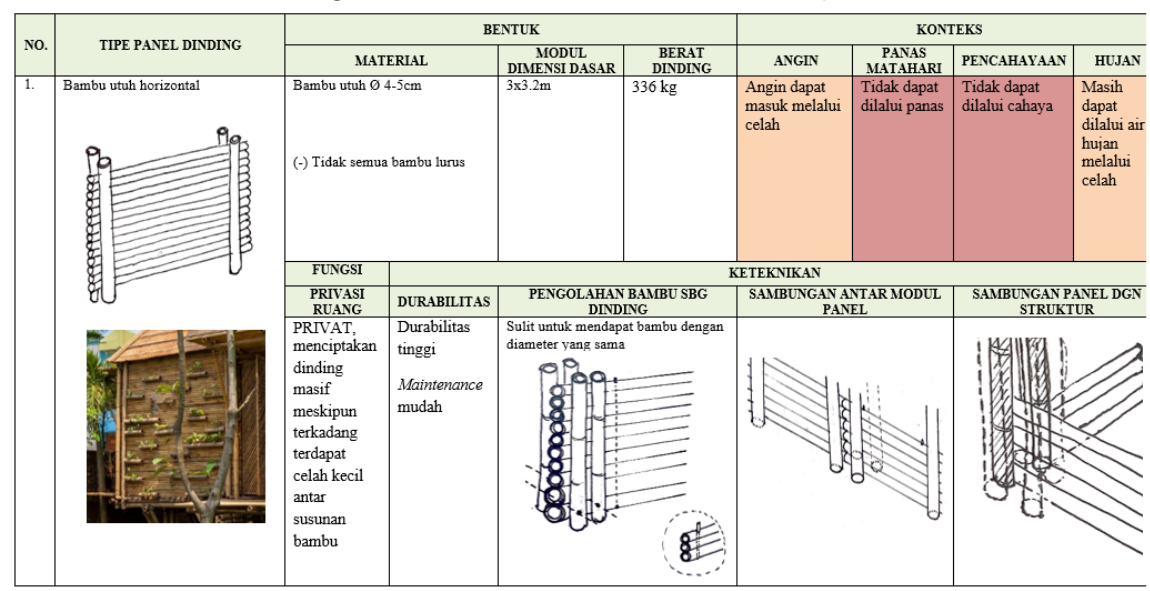

Tidak dapat dialuai $\quad$ Masih dapat dialabi $\square$ Dapat dilatui

Tabel 2. Dinding Bambu Bilah Horizontal Blooming Bamboo Home

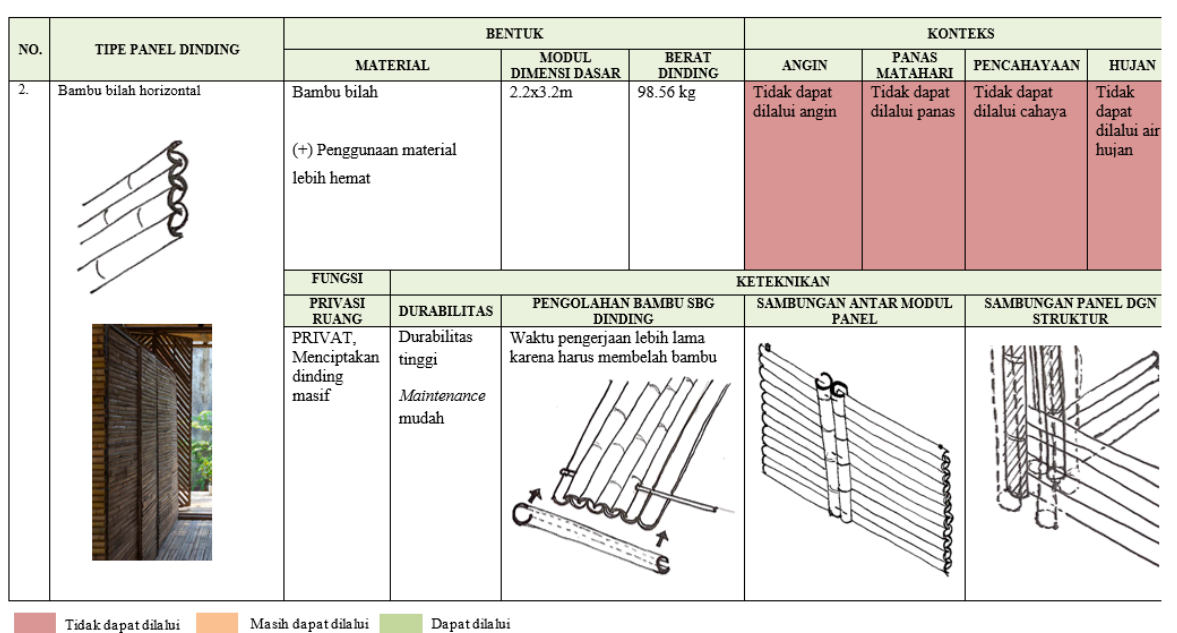


Tabel 3 Dinding Bambu Bilah Horizontal Blooming Bamboo Home

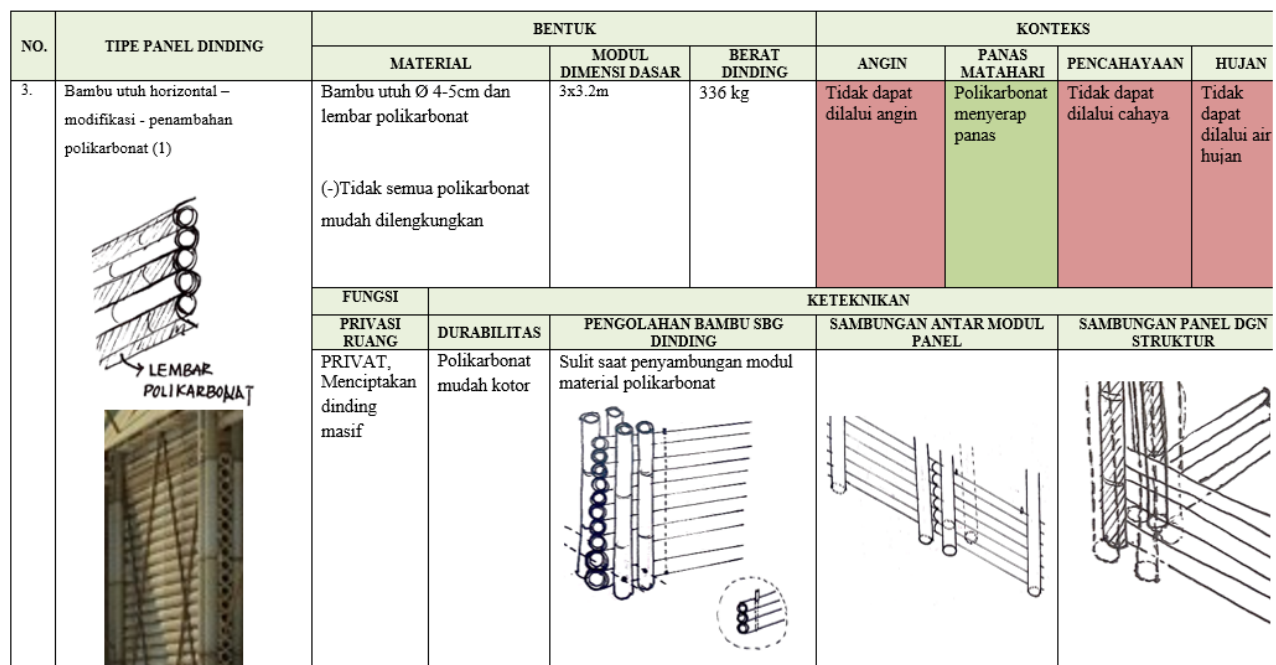

Tidak dapat dilalui $\quad$ Masih dapat dilalui $\square$ Dapat dilalui

Tabel 4. Dinding Bambu Utuh Horizontal modifikasi I Blooming Bamboo Home

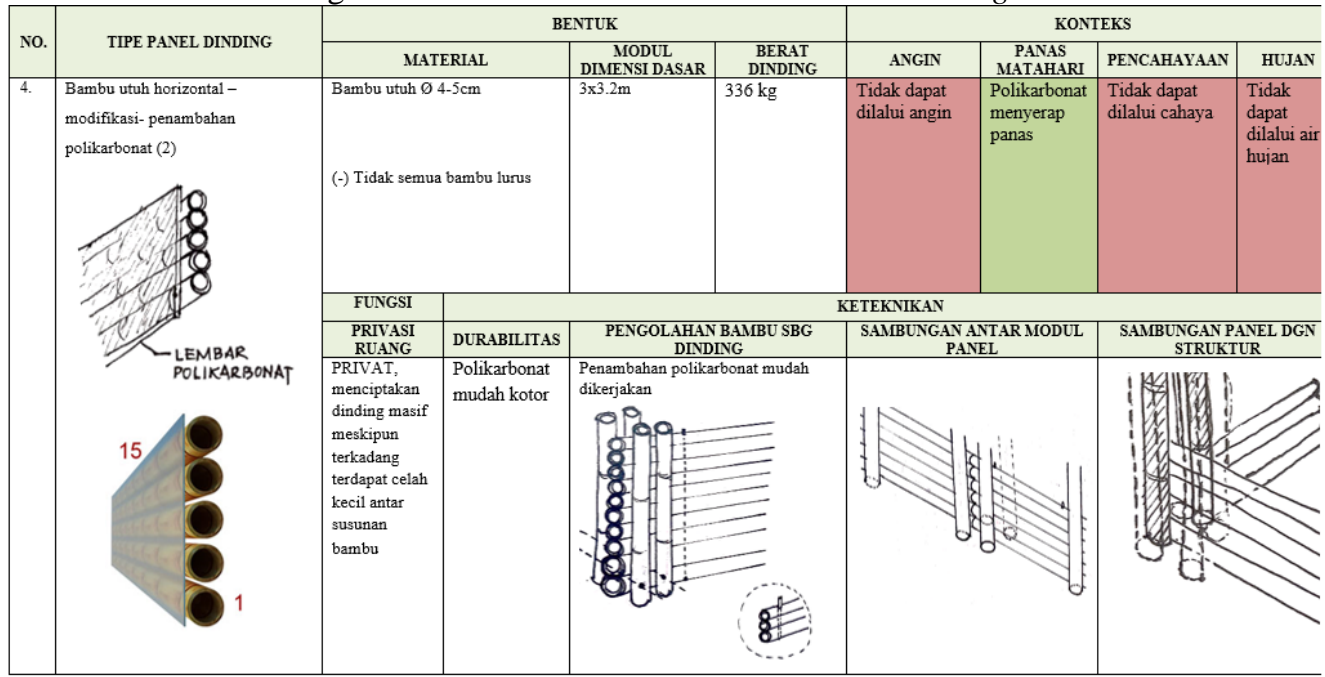

Tidak dapat dilalui _ـ Masih dapat dilalui _ـ Dapat dilalui

Tabel 5. Dinding Bambu Bilah Modifikasi II Blooming Bamboo Home

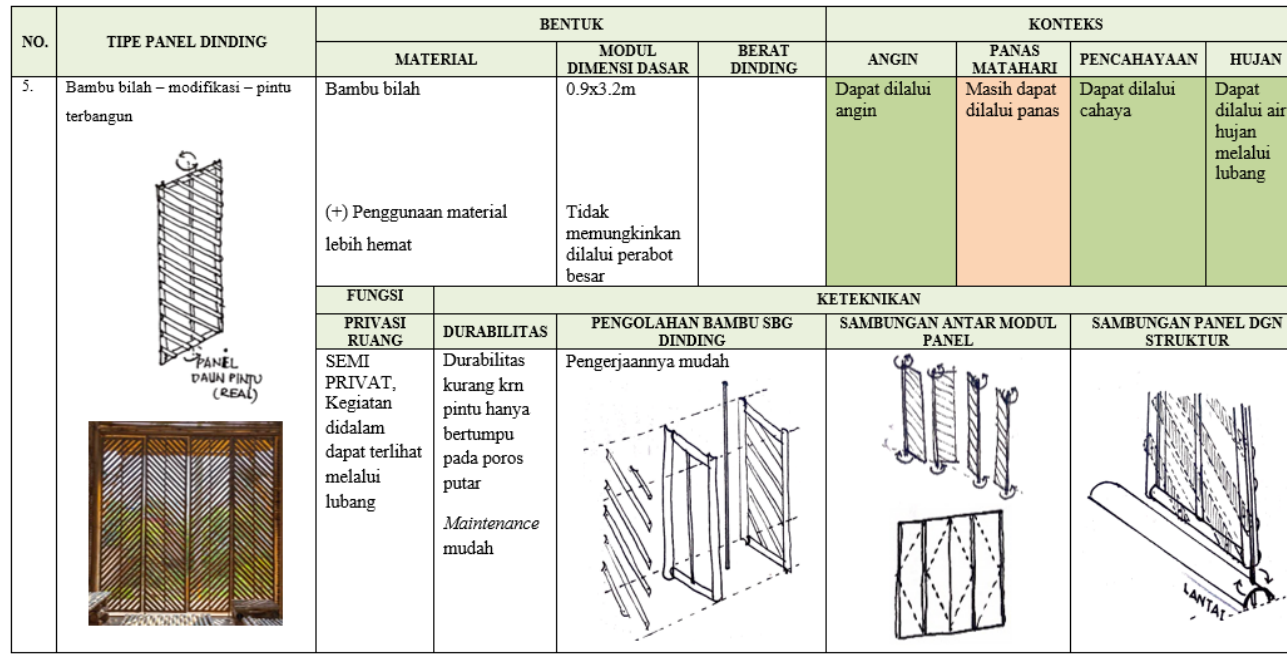

Tidak dapat dilalui $\quad$ Mash dapat dialui $\quad$ Dapat dilalui 
Tabel 6. Dinding Bambu Bilah Modifikasi Rencana Pintu Blooming Bamboo Home

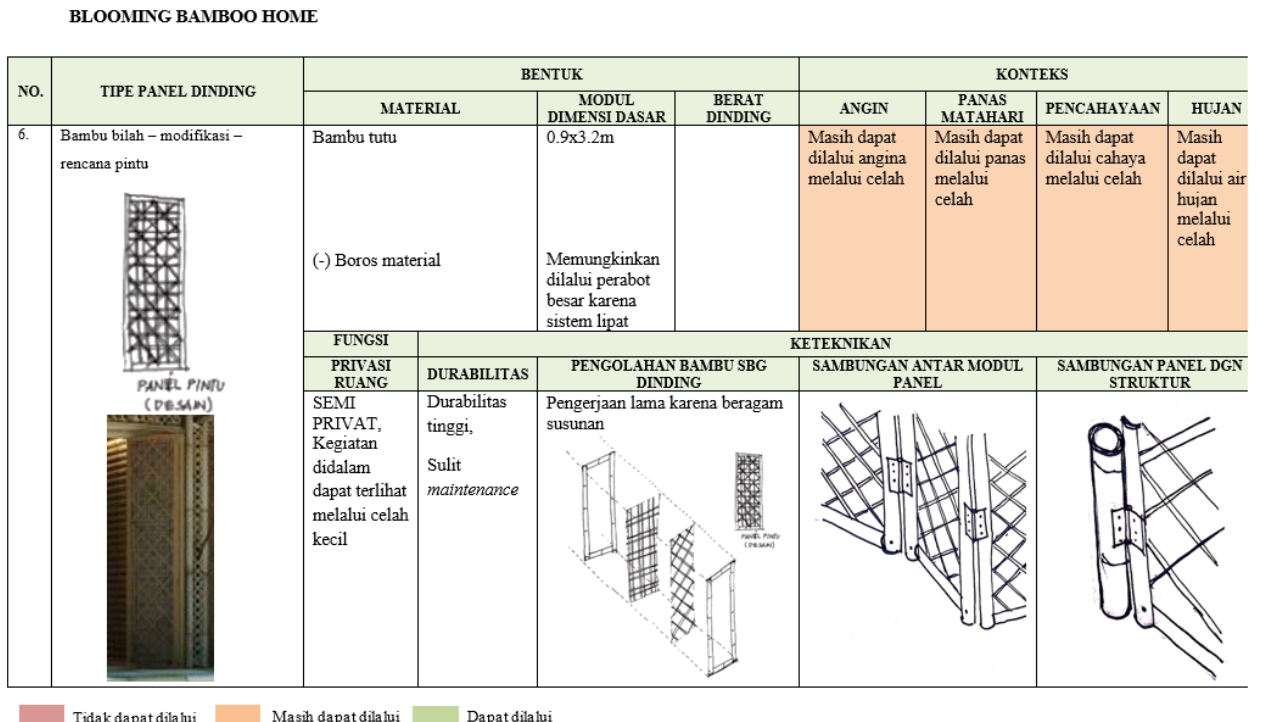

Dinding bambu pada Blooming Bamboo Home memiliki beberapa kelebihan dan kekurangan. Kelebihan dari dinding bangunan ini adalah adanya varian dinding dengan spesifikasi yang beragam sehingga mampu memenuhi kebutuhan ruang privat maupun publik. Modifikasi dinding bambu untuk memberikan nilai lebih dan melengkapi kekurangan dari dinding juga merupakan kelebihan dinding Blooming Bamboo Home. Kekurangan dinding bangunan ini adalah ukuran modul dinding yang terlalu besar apabila dijadikan sebagai panel dinding bambu knock down. Material bambu utuh sebagai panel dinding knock down tidak tepat digunakan karena berat total dinding menjadi pertimbangan dalam hal mobilisasi. Efisiensi waktu pengerjaannya yang lama karena dikerjakan langsung pada lokasi padahal fungsi Blooming Bamboo Home adalah rumah untuk para korban bencana sehingga kecepatan dalam pembangunan merupakan hal yang harus diperhatikan.

\subsection{DINDING PADA SOE KER TIE HOUSE}

Tabel 7. Dinding Bambu Utuh Modifikasi Horizontal Soe Ker Tie House

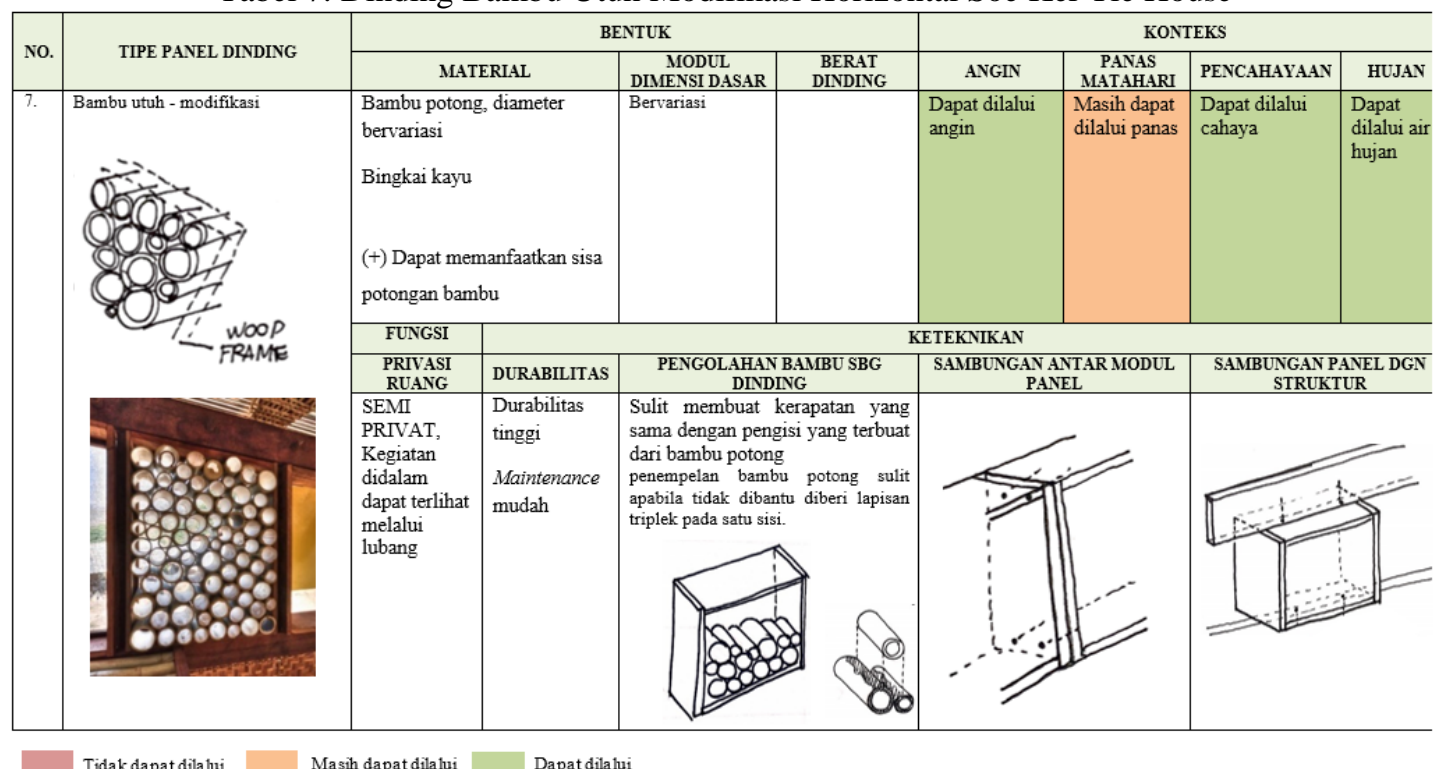


Tabel 8. Dinding Anyaman Bambu Soe Ker Tie House

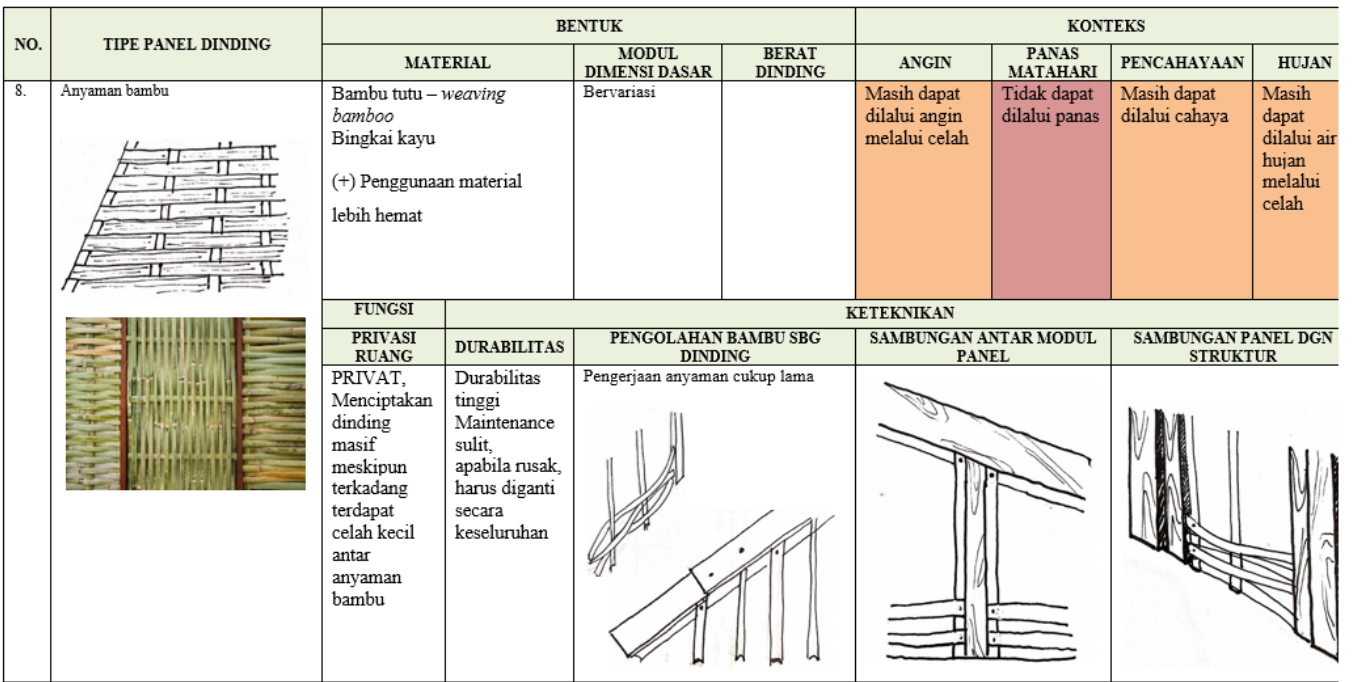

Tidak dapat dilatui $\quad$ Masih dapat dilalui $\square$ Dapat dilalui

Tabel 9. Dinding Anyaman Bambu Bilik Soe Ker Tie House

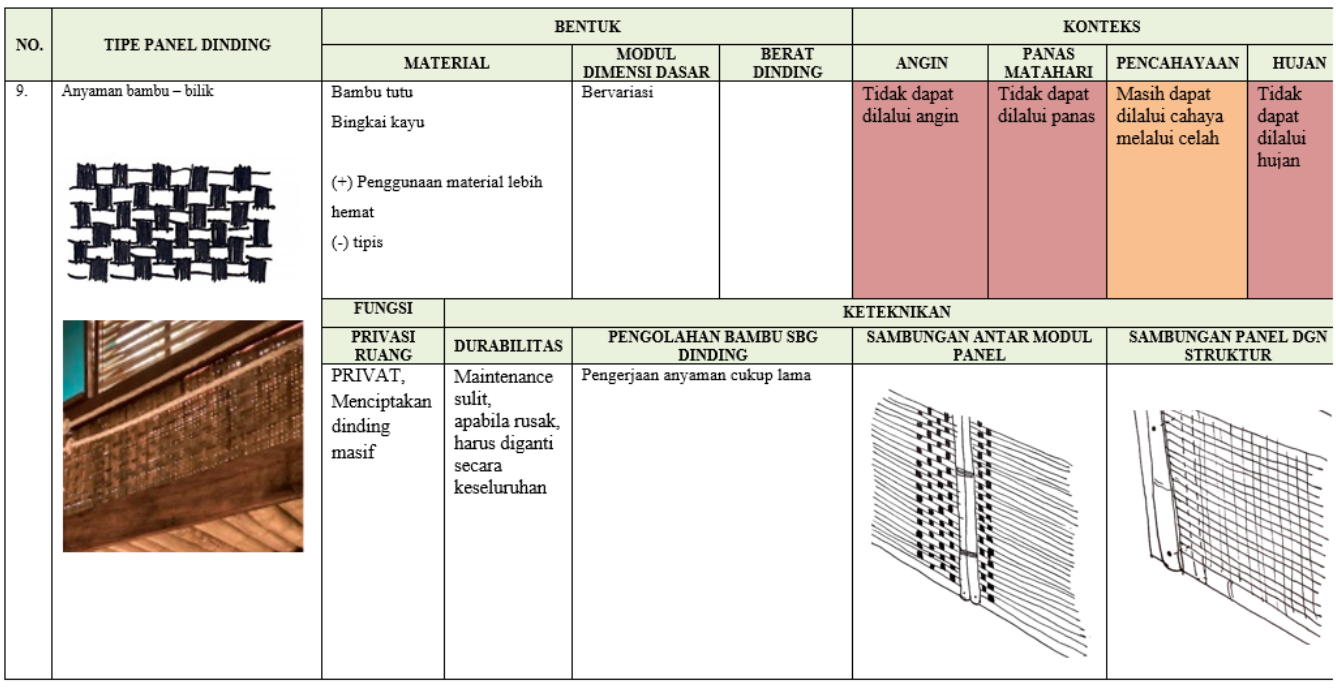

Tidak dapat dilalui —_ Masih dapat dila lui —_ Dapatdilalui

Tabel 10. Dinding Bambu Bilah Pintu Soe Ker Tie House

\begin{tabular}{|c|c|c|c|c|c|c|c|c|c|}
\hline \multirow[b]{2}{*}{ No. } & \multirow{2}{*}{ TIPE PANEL DINDING } & \multicolumn{4}{|c|}{ BENTUK } & \multicolumn{4}{|c|}{ KONTEKS } \\
\hline & & \multicolumn{2}{|c|}{ MATERIAL } & $\begin{array}{c}\text { MODUL } \\
\text { DIMENSI DASAR }\end{array}$ & $\begin{array}{c}\text { BERAT } \\
\text { DINDING }\end{array}$ & ANGIN & $\begin{array}{c}\text { PANAS } \\
\text { MATAHARI }\end{array}$ & PENCAHAYAAN & HUJAN \\
\hline \multirow[t]{4}{*}{10.} & \multirow{4}{*}{ Bambu bilah - pintu } & \multicolumn{2}{|c|}{$\begin{array}{l}\text { Bambu bilah } \\
\text { Rangka kayu } \\
\text { (-) Diameter bambu berbeda- } \\
\text { beda }\end{array}$} & $2.1 \times 0.8$ & $23.52 \mathrm{~kg}$ & $\begin{array}{l}\text { Tidak dapat } \\
\text { dilalui angin }\end{array}$ & $\begin{array}{l}\text { Tidak dapat } \\
\text { dilalui panas }\end{array}$ & $\begin{array}{l}\text { Tidak dapat } \\
\text { dilalui cahaya }\end{array}$ & $\begin{array}{l}\text { Tidak } \\
\text { dapat } \\
\text { dilalui air } \\
\text { hujan }\end{array}$ \\
\hline & & FUNGSI & & & & ETEKNIKAN & & & \\
\hline & & $\begin{array}{c}\text { PRIVASI } \\
\text { RUANG } \\
\end{array}$ & DURABILITAS & \multicolumn{2}{|c|}{$\begin{array}{c}\begin{array}{c}\text { PENGOLAHAN BAMBU SBG } \\
\text { DINDING }\end{array} \\
\end{array}$} & $\begin{array}{r}\text { SAMBUNGAN } \\
\text { PA } \\
\end{array}$ & $\begin{array}{l}\text { NTAR MODUL } \\
\text { EL }\end{array}$ & \multicolumn{2}{|c|}{$\begin{array}{c}\text { SAMBUNGAN PANEL DGN } \\
\text { STRUKTUR }\end{array}$} \\
\hline & & $\begin{array}{l}\text { PRIVAT, } \\
\text { Menciptakan } \\
\text { pintu masif }\end{array}$ & $\begin{array}{l}\text { Durabilitas } \\
\text { tinggi } \\
\text { Maintenance } \\
\text { mudah }\end{array}$ & 1 & E & & & : & 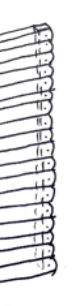 \\
\hline
\end{tabular}

Tidak dapat dilalui $\square$ Masih dapat dilalui $\quad$ Dapat dilalui 
Tabel 11. Dinding Anyaman Bambu modifikasi I Soe Ker Tie House

\begin{tabular}{|c|c|c|c|c|c|c|c|c|c|}
\hline \multirow{2}{*}{ No. } & \multirow{2}{*}{ TIPE PANEL DINDING } & \multicolumn{4}{|c|}{ BENTUK } & \multicolumn{4}{|c|}{ KONTEKS } \\
\hline & & \multicolumn{2}{|c|}{ MATERIAL } & $\begin{array}{c}\text { MODUL } \\
\text { DIMENSI DASAR }\end{array}$ & $\begin{array}{l}\text { BERAT } \\
\text { DINDING }\end{array}$ & ANGIN & $\begin{array}{c}\text { PANAS } \\
\text { MATAHARI }\end{array}$ & PENCAHAYAAN & HUJAN \\
\hline \multirow[t]{4}{*}{11.} & \multirow[t]{4}{*}{$\begin{array}{l}\text { Anyaman bambu - modifikasi - } \\
\text { penambahan polikarbonat }\end{array}$} & \multicolumn{2}{|c|}{$\begin{array}{l}\text { Bambu tutu } \\
\text { Polikarbonat } \\
\text { Bingkai kayu } \\
\text { (+) Penggunaan material } \\
\text { lebih hemat }\end{array}$} & Bervariasi & & $\begin{array}{l}\text { Tidak dapat } \\
\text { dilalui angin }\end{array}$ & $\begin{array}{l}\text { Polikarbonat } \\
\text { menyerap } \\
\text { panas }\end{array}$ & $\begin{array}{l}\text { Masih dapat } \\
\text { dilalui cahaya } \\
\text { melalui celah } \\
\text { anyaman }\end{array}$ & $\begin{array}{l}\text { Tidak } \\
\text { dapat } \\
\text { dilalui air } \\
\text { hujan }\end{array}$ \\
\hline & & FUNGSI & \multicolumn{7}{|c|}{ KETEKNIKAN } \\
\hline & & $\begin{array}{c}\text { PRIVASI } \\
\text { RUANG } \\
\end{array}$ & DURABILITAS & $\begin{array}{r}\text { PENGOLAHAN } \\
\text { DIND }\end{array}$ & MBU SBG & $\begin{array}{r}\text { SAMBUNGAN } \\
\text { PA }\end{array}$ & $\begin{array}{l}\text { TTAR MODUL } \\
\text { L }\end{array}$ & $\begin{array}{r}\text { SAMBUNGAN } \\
\text { STRUK }\end{array}$ & $\begin{array}{l}\text { UNEL DGN } \\
\text { UR }\end{array}$ \\
\hline & & $\begin{array}{l}\text { PRIVAT, } \\
\text { menciptakan } \\
\text { dinding } \\
\text { masif } \\
\text { meskipun } \\
\text { terkadang } \\
\text { terdapat } \\
\text { celah kecil } \\
\text { antar } \\
\text { anyaman } \\
\text { bambu }\end{array}$ & $\begin{array}{l}\text { Polikarbonat } \\
\text { mudah kotor } \\
\text { Apabila } \\
\text { dinding } \\
\text { anyaman } \\
\text { rusak, harus } \\
\text { diganti secara } \\
\text { keseluruhan, } \\
\text { Penggantian } \\
\text { polikarbonat } \\
\text { mudah }\end{array}$ & $\begin{array}{l}\text { Penambahan poli } \\
\text { dikerjakan }\end{array}$ & Donat mudah & & & & \\
\hline
\end{tabular}

Tidak dapat dilalui _. Masih dapat dilatui Dapat dilalui

Tabel 12. Dinding Bambu Bilah Horizontal Soe Ker Tie House

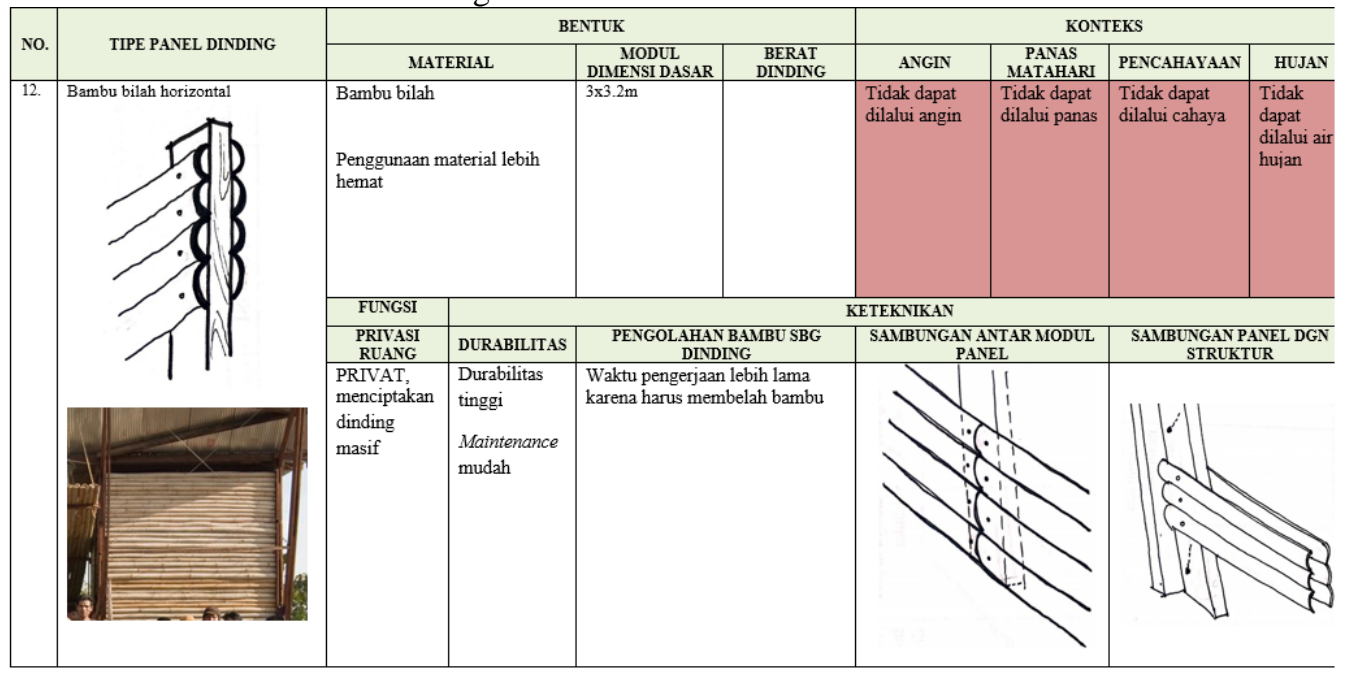

Tidak dapat dilalui $\quad$ Masih dapat dilalui $\quad$ Dapat dilalui

Dinding pada Soe Ker Tie House juga memiliki kelebihan dan kekurangan. Kelebihannya adalah pengolahan material bambu menjadi varian dinding dengan spesifikasi yang beragam. Penciptaan dinding masif dengan menggunakan bambu setengah sehingga dinding yang dihasilkan lebih ringan. Kekurangan dari dinding Soe Ker Tie House adalah dinding bambu dikerjakan langsung pada lokasi sehingga tidak efisien waktu, dan sambungan tidak memungkinkan dinding bambu dapat dibongkar pasang.

\subsection{KESIMPULAN APLIKASI PANEL DINDING BAMBU PADA OBJEK STUDI}

Berdasarkan analisis komparasi panel dinding bambu objek studi dan pertimbangan beberapa hal dalam membuat pengisi panel dinding bambu yang telah dibahas diatas, maka didapat varian pengisi dinding yang paling efektif dalam efisien untuk dijadikan panel dinding bambu knock down yang dikelompokkan berdasarkan derajat keterbukaannya. Berikut merupakan varian pengisi dinding tersebut : 


\section{Masif}

(1)

\section{Bambu Bilah Vertikal}

Dinding bambu bilah setengah ini digunakan pada Blooming Bamboo Home dan Soe

Ker Tie House namun arah susunan bambu diubah menjadi vertikal agar searah dengan air hujan. Kebutuhan bambu dalam pembuatan dinding lebih hemat namun tetap dapat menciptakan dinding masif dengan privasi ruang yang bersifat privat. Durabilitas dinding tinggi dan perawatannya mudah dilakukan. Pembersihan dinding dapat dilakukan dengan cara dilap dan mudah untuk melakukan penggantian bambu yang rusak.Angin, panas matahari, cahaya, dan air hujan tidak dapat melalui dinding bambu bilah vertikal.
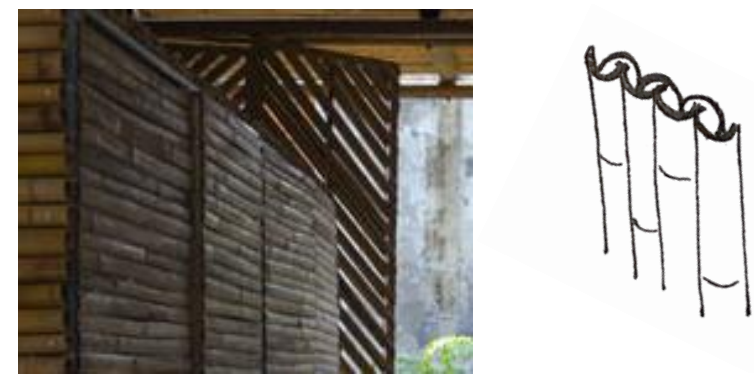

Figur 2. Dinding Bambu Bilah Horizontal Blooming Bamboo Home dan Ilustrasi Sumber: www.dezeen.com dan dokumentasi pribadi

(2) Anyaman Bambu Bilik

Dinding anyaman bambu bilik digunakan pada Soe Ker Tie House. Kelebihan dinding ini adalah penggunaan material bambu yang hemat. Menciptakan dinding masif dengan privasi ruang yang bersifat privat. Dinding yang tipis dapat diatasi dengan mendobel anyaman bambu bilik dan memasang rangka bambu bilah diantara dua sisi anyaman bambu bilik sehingga menghasilkan dinding yang lebih kuat. Pembersihan dinding dapat dilakukan dengan cara dilap. Kekurangan dari dinding ini adalah apabila dinding rusak, penggantian harus dilakukan secara keseluruhan dan pengerjaan anyaman membutuhkan waktu yang cukup lama. Angin, panas matahari, dan air hujan tidak dapat melalui dinding ini, namun masih dapat dilalui cahaya.
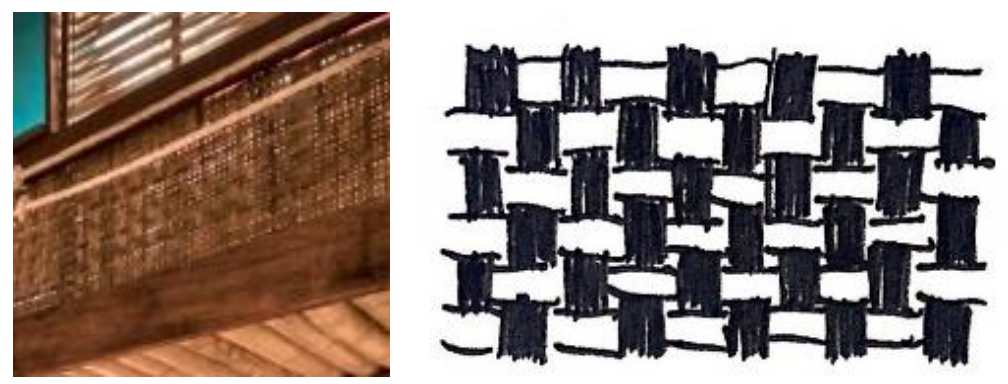

Figur 3. Dinding Anyaman Bambu Soe Ker Tie House dan Ilustrasi Sumber: www.archdaily.com diakses 9 Maret 2017 dan dokumentasi pribadi

\section{Semi Terbuka}

(1) Anyaman Bambu

Dinding anyaman bambu digunakan pada Soe Ker Tie House. Penggunaan material bambu untuk membuat dinding anyaman bambu hemat. Dinding tergolong pada kategori semi terbuka karena masih terdapat celah kecil diantara anyaman bambu namun masih menciptakan dinding masif dengan privasi ruang yang bersifat privat. Pembersihan dinding dapat dilakukan dengan cara dilap namun apabila dinding bambu rusak, harus dilakukan penggantian secara 
keseluruhan. Pengerjaan anyaman bambu cukup lama. Angin, air hujan, dan cahaya matahari masih dapat melalui celah pada dinding. Panas matahari tidak dapat melalui dinding ini.

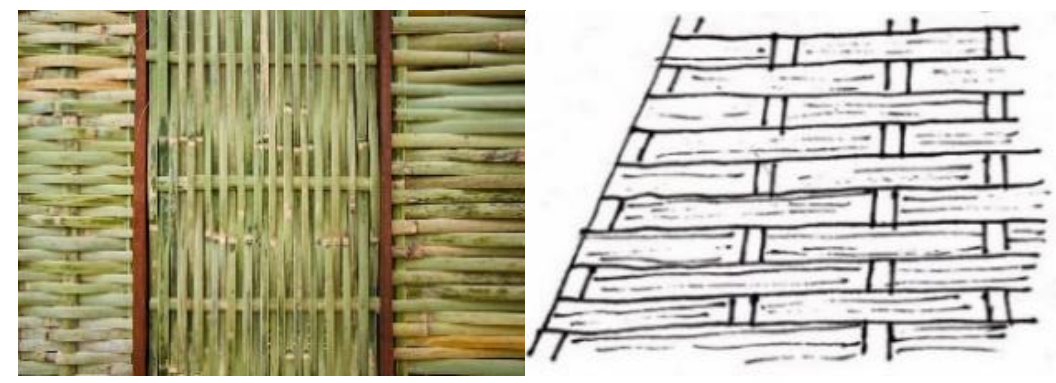

Figur 4. Dinding Anyaman Bambu Soe Ker Tie House dan Ilustrasi Sumber: www.archdaily.com dan dokumentasi pribadi

(2) Bambu Bilah Modifikasi I

Varian bambu bilah modifikasi digunakan pada Blooming Bamboo Home untuk rencana pintu. Bambu bilah disusun tumpeng tindih dengan arah diagonal yang berlawanan. Privasi ruang yang tercipta adalah semi privat karena kegiatan didalam dapat terlihat melalui celah dinding.

Durabilitas dinding bambu bilah modifikasi I tinggi. Tumpukan susun diubah menjadi dua susun agar tidak boros material dan agar penggantian bambu yang rusak mudah dilakukan. Angin, panas matahari, cahaya, dan air hujan masih dapat masuk melalui celah dinding.

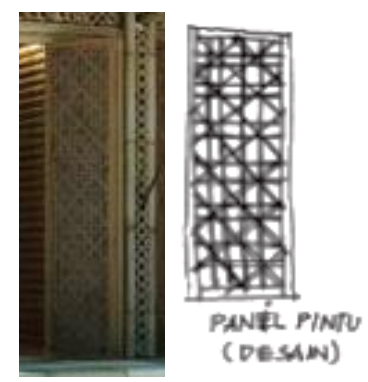

Figur 5. Dinding Bambu Bilah Modifikasi Blooming Bamboo Home dan Ilustrasi Sumber: www.dezeen.com dan dokumentasi pribadi

\section{Terbuka}

(1) Bambu Bilah Modifikasi II

Dinding bambu bilah modifikasi II digunakan pada Blooming Bamboo Home. Dinding ini termasuk pada kategori derajat keterbukaan terbuka karena kegiatan didalam dapat terlihat melalui lubang dinding. Privasi ruang yang tercipta bersifat semi privat. Pengerjaan dinding ini mudah dan penggantian bambu yang rusak tidak harus dilakukan secara keseluruhan. Angin, cahaya, dan air hujan dapat masuk melalui lubang dinding. Panas matahari masih dapat masuk melalui dinding.

(2) Polikarbonat

Dinding polikarbonat merupakan pengembangan dari dinding pada Blooming Bamboo Home dan Soe Ker Tie House yang menggunakan penambahan lembar polikarbonat. Polikarbonat dipilih karena harganya yang terjangkau, ringan, dan mudah dimaintenance. Polikarbonat yang digunakan tidak tembus pandang sehingga masih bersifat semi privat namun masih dapat meneruskan cahaya. 


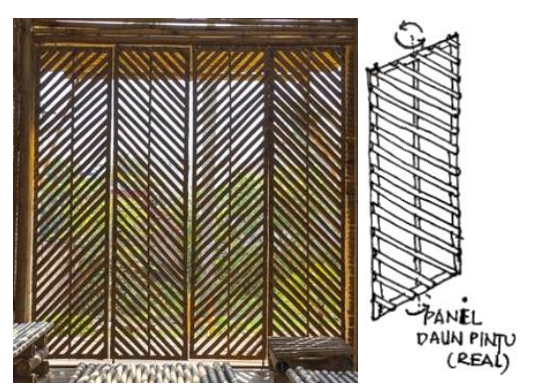

Figur 6. Dinding Bambu Bilah II Modifikasi Blooming Bamboo Home dan Ilustrasi Sumber: www.dezeen.com dan dokumentasi pribadi

Angin dan air hujan tidak dapat masuk melalui dinding ini namun kekurangan dinding polikarbonat ini adalah bahannya yang menyerap panas matahari tetapi cahaya dapat menembus dinding polikarbonat.
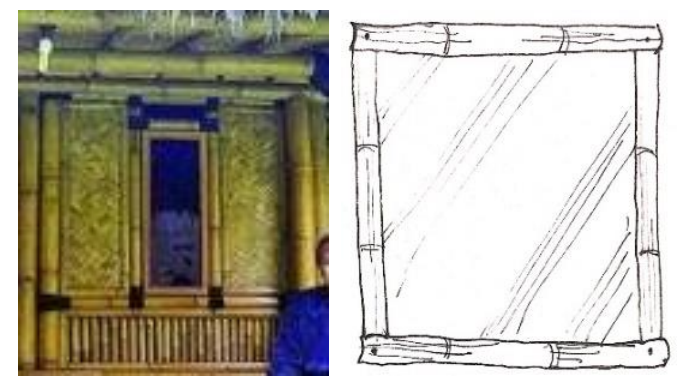

Figur 7. Aplikasi Dinding Polikarbonat dan Ilustrasi Sumber: www.alamy.com dan dokumentasi pribadi

\section{EKSPERIMEN PANEL DINDING BAMBU KNOCK DOWN}

Panel dinding bambu knock down dibuat dengan tujuan untuk mendukung pembangunan bangunan transisi yang sustainable, cepat pemasangannya, dan mudah dimobisasi. Pada eksperimen yang dilakukan, panel dinding bambu knock down akan diaplikasikan pada Shelter Bambu dan Bumi Awi Kabula Kabale. Shelter bambu adalah bangunan dengan struktur deployable dan Bumi Awi Kabula Kabale merupakan bangunan dengan sistem knock down. Bangunan tersebut belum memiliki dinding sehingga pemasangan panel dinding bambu knock down akan mendukung fungsi kedua bangunan. Kedua bangunan dipilih karena merupakan bangunan penelitian arsitektur UNPAR dan Shelter Bambu merupakan bangunan penelitian lanjutan skripsi Bernadette Sudira. 


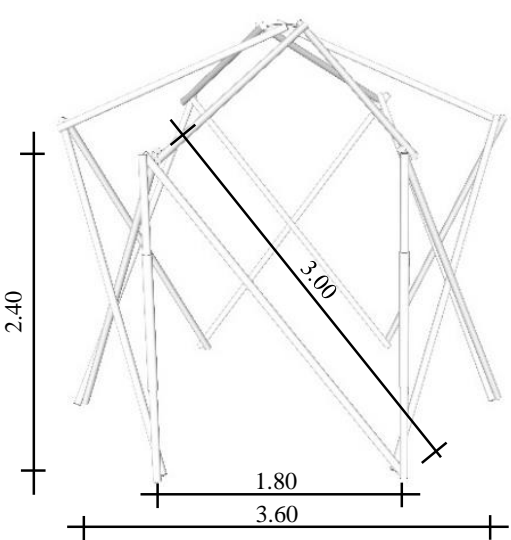

(a)

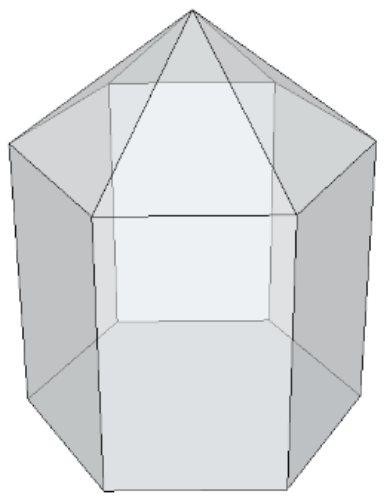

(b)

Figur 8. (a) Shelter Bambu (b) Ilustrasi Bentuk Segienam Shelter Bambu Sumber: Dokumentasi Pribadi

\subsection{SHELTER BAMBU}

Shelter Bambu memiliki bentuk segi enam degan sistem struktur deployable. Bentuk segi enam sangat berpotensi untuk dibuat modular secara horizontal maupun vertikal. Atap yang digunakan juga berbentuk segi enam dengan sistem struktur atap resiprokal.

Bentangan satu sisi bangunan adalah 1.80 meter sehingga bentangan terjauh bangunan mencapai 3.60 meter. Sisi dinding bangunan terdiri dari sub-sub modul X yang berketinggian 2.40 meter. Bambu submodul X memiliki panjang 3 meter sehingga efektif dalam penggunaan material bambu pada umumnya yang tersedia dengan panjang 6 meter.

\subsection{BUMI AWI KABULA KABALE (BAKK)}
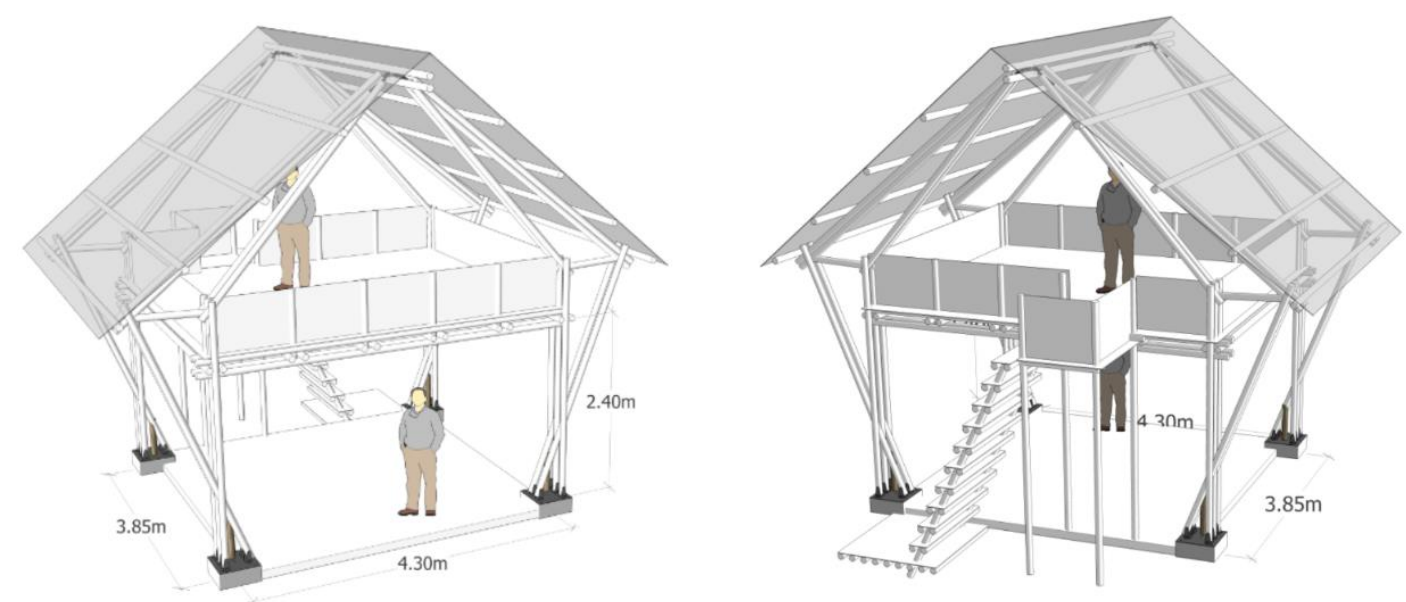

Figur 9. Model Bumi Awi Kabula Kabale Sumber: Dokumentasi BAKK

Bumi Awi Kabula Kabale bangunan yang terbuat dari bambu modular dengan panjang yang dapat disesuaikan. Kebutuhan akan bangunan yang dapat menanggapi berbagai kebutuhan dengan keadaan tertentu semakin banyak, namun juga diharapkan praktis dalam pembangunan dan dapat menyesuaikan diri dengan lahan yang tersedia.

Struktur bangunan menggunakan portal knock down yang terbuat dari bambu dengan sistem jepit. Portal bambu tersebut menyambung dengan pedestal beton menggunakan pelat besi dengan sambungan mur baut ke portal bambu. BAKK memiliki 4 portal bambu. Modul panel dinding bambu knock down diharapkan dapat diaplikasikan pada Bumi Awi Kabula 
Kabale karena memiliki prinsip yang sama yaitu sistem knock down sehingga mendukung fungsi bangunan. Penyesuaian besar modul bangunan BAKK disesuaikan dengan besar modul panel dinding bambu knock down sehingga mempermudah pembangunan BAKK ketika dibutuhkan pengaplikasian dinding. Luasan BAKK disesuaikan menjadi 3.85 x 4.30 meter dengan tinggi ring balok atas 2.40 meter. Panjang bangunan membutuhkan 5 panel dinding bambu knock down, lebar bangunan membutuhkan 4 panel dinding bambu knock down.

\subsection{EKSPERIMEN PANEL DINDING BAMBU KNOCK DOWN}

Pertimbangan pembuatan modul dinding didasarkan pada 4 hal, yakni (1)Dapat dimobilisasi dengan mobil pick-up atau helicopter (2) Mudah diangkut oleh 1 atau 2 orang (3) Sambungan antar modul mudah dan tidak terlalu banyak (4) Pertimbangan modul pintu. Pertimbangan pengisi modul dinding didasarkan pada 4 hal. Hal tersebut adalah (1)Banyak material yang digunakan (2)Berat dinding (3)Derajat keterbukaan (masif, semi-terbuka, terbuka) (4)Kecepatan pengerjaan.

\section{Bentuk Dinding}

Modul panel dinding knock down disesuaikan dengan Shelter Bambu yang juga dapat diaplikasikan pada bangunan Bumi Awi Kabula Kabale.

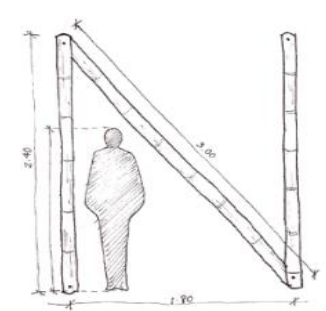

(a)

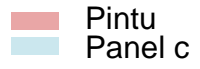

Figur 10. (a) Struktur Shelter Bambu pada Bagian Entrance

(b)Pembagian Modul Panel Dinding Bambu pada Struktur Bagian Entrance Sumber: Dokumentasi Pribadi

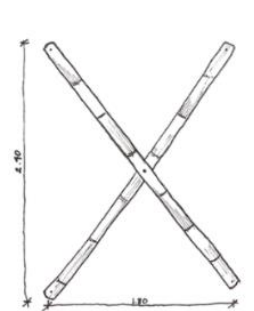

(a)

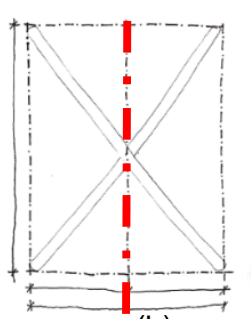

(b)

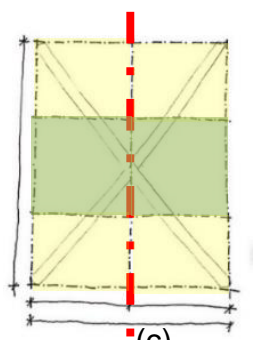

Panel a Panel b
Figur 11. (a) Struktur Submodul X Shelter Bambu (b)Pembagian Simetris Modul pada Struktur Submodul X

(c) Pembagian Modul Panel Dinding Sumber: Dokumentasi Pribadi

Modul dinding pada Shelter Bambu berukuran lebar 90 cm dan panjang $2.40 \mathrm{~m}$ dengan dua tipe jenis yakni dinding dan pintu. Berikut merupakan tabel perhitungan jumlah batang bambu $\varnothing 10 \mathrm{~cm}$ yang digunakan untuk membuat satu bingkai modul panel :

Dari tabel diatas dapat disimpulkan bahwa untuk satu shelter bambu membutuhkan 11 bingkai modul dinding dan 1 bingkai modul pintu sehingga bambu yang dibutuhkan sebanyak 16 batang bambu $\varnothing 10 \mathrm{~cm}$. 


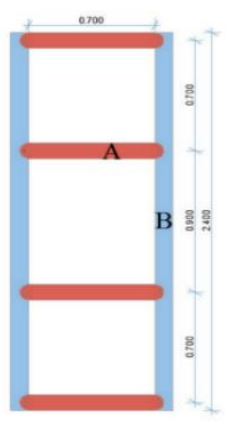

Figur 12. Bingkai Modul Dinding Sumber: Dokumentasi Pribadi

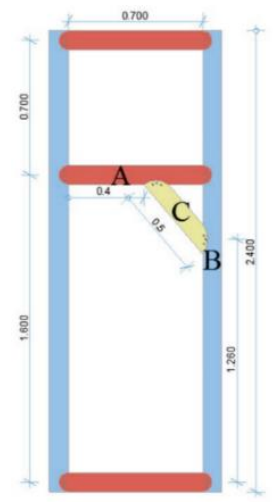

Figur 13. Bingkai Modul Pintu Sumber: Dokumentasi Pribadi

\begin{tabular}{|c|c|c|c|c|}
\hline \multirow[b]{2}{*}{ No. } & \multirow[b]{2}{*}{ Jenis Modul } & \multirow[b]{2}{*}{ Jumlah } & \multicolumn{2}{|c|}{ Panjang Batang } \\
\hline & & & $\begin{array}{c}\text { Panjang } \\
\text { Satuan }\end{array}$ & $\begin{array}{c}\text { Total } \\
\text { Panjang }\end{array}$ \\
\hline 1. & Bambu A (horizontal) & 4 & $0.70 \mathrm{~m}$ & $2.80 \mathrm{~m}$ \\
\hline 2. & Bambu B (vertikal) & 2 & $2.40 \mathrm{~m}$ & $4.80 \mathrm{~m}$ \\
\hline & & & TOTAL & $7.60 \mathrm{~m}$ \\
\hline
\end{tabular}

Tabel 13. Perhitungan Jumlah Batang Bambu dalam Satu Bingkai Modul Pintu

Sumber: Dokumentasi Pribadi

\begin{tabular}{|c|c|c|c|c|}
\hline \multirow[b]{2}{*}{ No. } & \multirow[b]{2}{*}{ Jenis Modul } & \multirow[b]{2}{*}{ Jumlah } & \multicolumn{2}{|c|}{ Panjang Batang } \\
\hline & & & $\begin{array}{l}\text { Panjang } \\
\text { Satuan }\end{array}$ & $\begin{array}{c}\text { Total } \\
\text { Panjang }\end{array}$ \\
\hline 1. & Bambu A (horizontal) & 3 & $0.70 \mathrm{~m}$ & $2.10 \mathrm{~m}$ \\
\hline 2. & Bambu B (vertikal) & 2 & $2.40 \mathrm{~m}$ & $4.80 \mathrm{~m}$ \\
\hline 3. & Bambu C (diagonal) & 1 & $0.50 \mathrm{~m}$ & $0.50 \mathrm{~m}$ \\
\hline & & & TOTAL & $7.40 \mathrm{~m}$ \\
\hline
\end{tabular}

Tabel 14. Perhitungan Jumlah Batang Bambu dalam Satu Bingkai Modul Pintu Sumber: Dokumentasi Pribadi

\section{Fungsi dan Konteks Dinding}

(1) Bambu Bilah Vertikal

Dinding bambu bilah menciptakan dinding masif dan privasi ruang privat. Susunan dinding bilah tumpang tindih membuat angin, panas, dan cahaya tidak dapat melalui dinding ini. Bambu bilah setengah disusun secara vertikal agar searah dengan arah mengalirnya air hujan.

(2) Anyaman Bambu Bilik

Dinding terbuat dari bambu tutu yang dianyam dengan pola berbentuk horizontal vertikal. Menghasilkan dinding masif dan privasi ruang rapat. Dinding tidak dapat dilalui angin, panas, dan hujan namun cahaya masih dapat masuk melalui celah dinding.

(3) Anyaman Bambu

Dinding anyaman bambu erbuat dari bambu bilah yang dianyam selang seling menyerupai ombak. Dinding ini menciptakan dinding semi terbuka karena terdapat celahcelah. Menghasilkan dinding semi privat. Angin, cahaya dan air hujan masih dapat masuk melalui celah dinding. Panas tidak dapat melalui dinding ini.

Bambu Bilah Modifikasi I

Dinding bambu bilah modifikasi I dari bambu bilah yang disusun tumpang tindih dengan arah yang berbeda. Kerapatan jarak menentukan jenis dinding yang dihasilkan, yakni semi terbuka atau terbuka. Privasi ruang yang dihasilkan bersifat semi privat Apabila ditambah dengan polikarbonat, dinding tidak dapat dilalui angin, hujan, dan panas tetapi cahaya masih 
dapat masuk melalui celah dinding. Namun apabila tidak diberi polikarbonat maka angin, panas, cahaya, dan hujan masih dapat masuk melalui celah dinding.

Bambu Bilah Modifikasi II

Dinding bambu bilah modifikasi II terbuat dari bambu bilah yang disusun berjarak. Kerapatan jarak menentukan jenis dinding yang dihasilkan, yakni semi terbuka atau terbuka. Menghasilkan privasi ruang yang bersifat semi privat karena kegiatan didalam dapat terlihat melalui lubang dinding. Lubang pada dinding menyebabkan angin, cahaya, panas, dan hujan masif dapat masuk.

(6) Polikarbonat

Dinding terbuat dari polikarbonat yang dipasang pada bingkai bambu. Menghasilkan dinding masif namun bersifat transparan sehingga menciptakan privasi ruang yang semi privat. Angin dan air hujan tidak dapat dilalui hujan. Cahaya dapat melalui dinding ini karena bersifat transparan. Polikarbonat menyerap panas sehingga panas masuk melalui pintu.

\section{Keteknikan Dinding}

Telah dijelaskan sebelumnya bahwa panel dinding bambu knock down harus mampu dilepas pasang dengan praktis sehingga dapat dipindah dengan mudah ke tempat lain yang membutuhkan. Oleh karena itu, sistem sambungan pada bambu yang tepat digunakan adalah sambungan mur baut dan sekrup. Sambungan pada panel dinding bambu knock down menggunakan sambungan skrup gypsum yang memang merupakan salah satu jenis sambungan knock down.
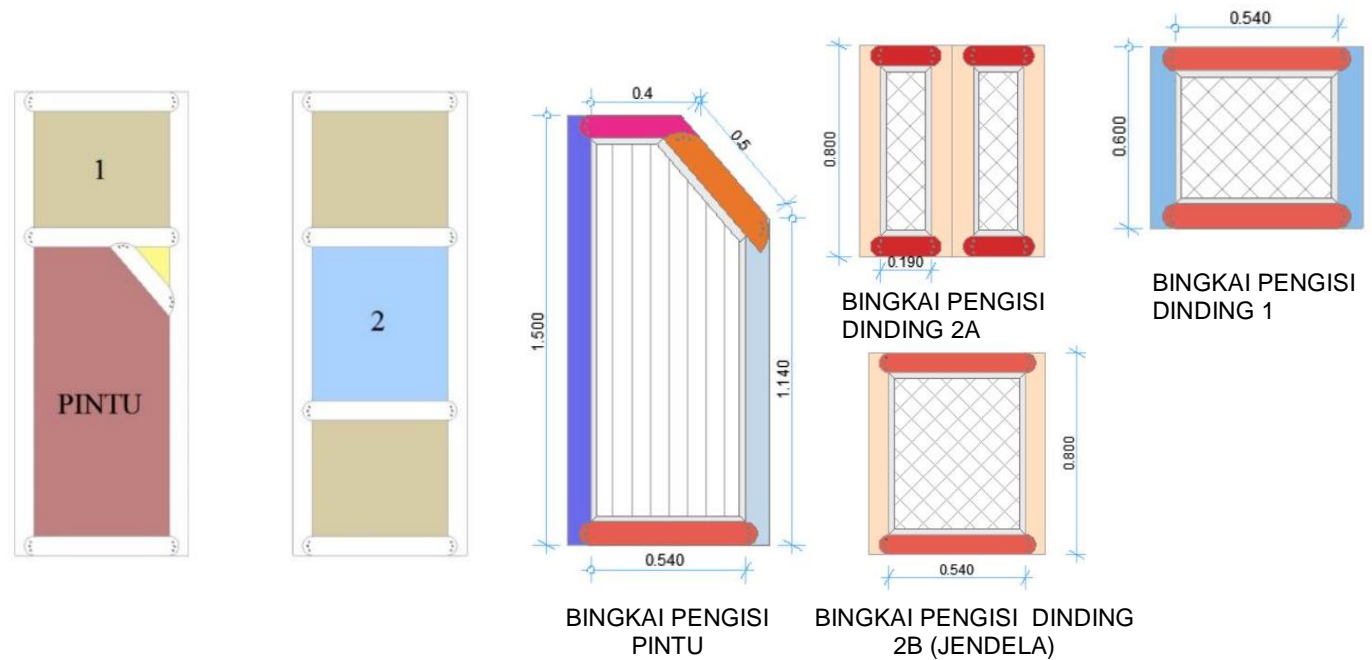

DINDING 1

Figur 14. Pengisi Panel Dinding Bambu Knock Down Sumber: Dokumentasi Pribadi 


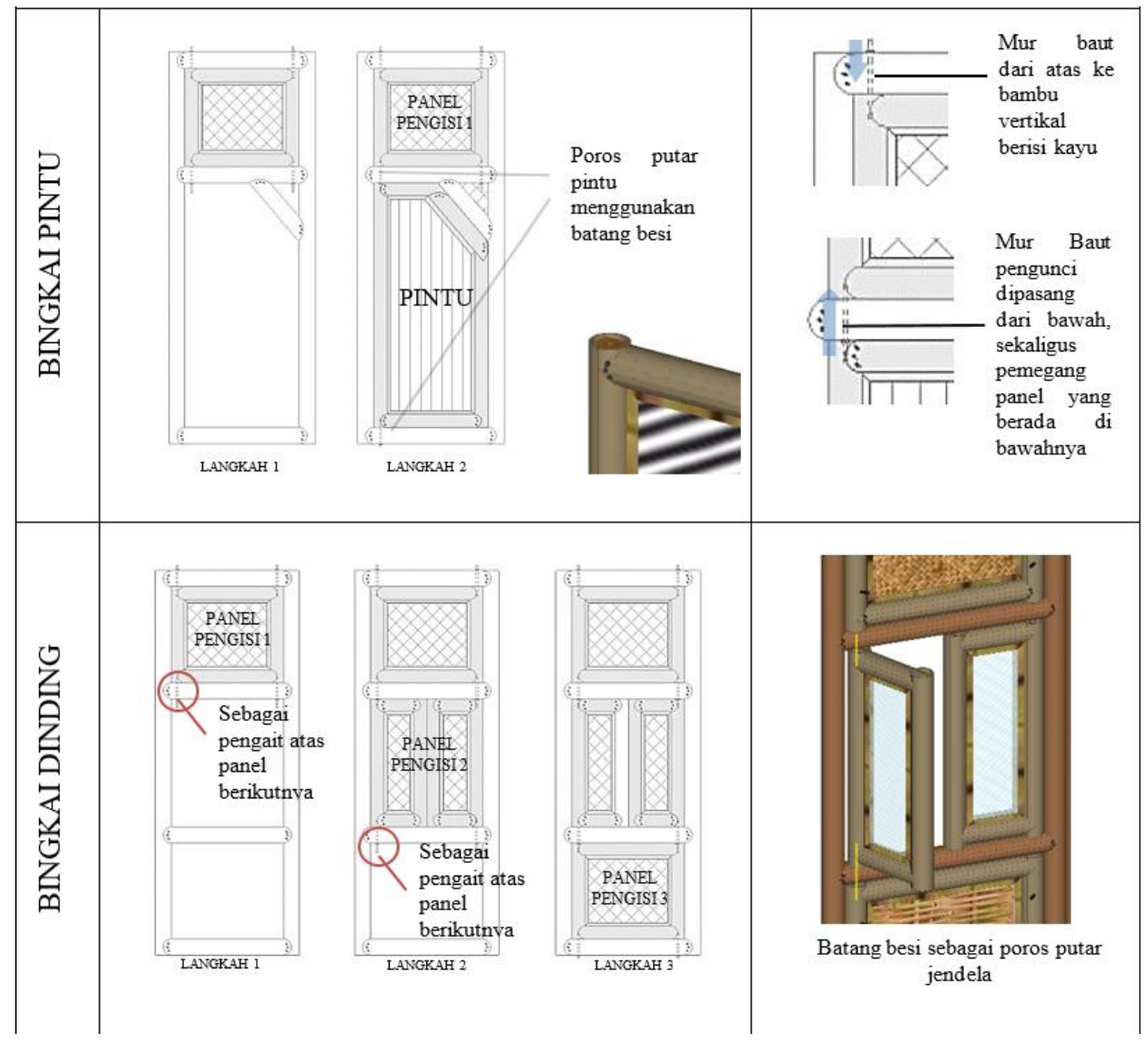

Figur 15. Sistem Sambungan Bingkai Panel Dinding Bambu Knock Down Sumber: Dokumentasi Pribadi

Sistem pemasangan bingkai pengisi ke bingkai panel dinding knock down menggunakan mur baut. Setiap bambu vertikal bingkai pengisi diberi tambahan balok kayu yang dilubangi untuk sambungan mur baut. Pemasangan panel pengisi harus dilakukan secara berurutan dari panel pengisi 1, panel pengisi 2, dan terakhir panel pengisi 3 karena mur baut pada bagian bawah bingkai pengisi akan menjadi sambungan ke panel pengisi berikutnya. Sama dengan opsi satu, engsel pintu dan jendela menggunakan tambahan balok kayu dan batang besi yang berfungsi sebagai poros putar.

\section{Keteknikan Dinding Shelter Bambu}

Untuk memasang panel dinding bambu knock down pada Shelter Bambu, hal pertama yang harus dilakukan adalah membuka struktur deployable Shelter Bambu. Kemudian setiap sudut pertemuan modul $\mathrm{X}$ diberi tiang bambu tambahan sebagai pemegang bingkai panel dinding bambu knock down. 

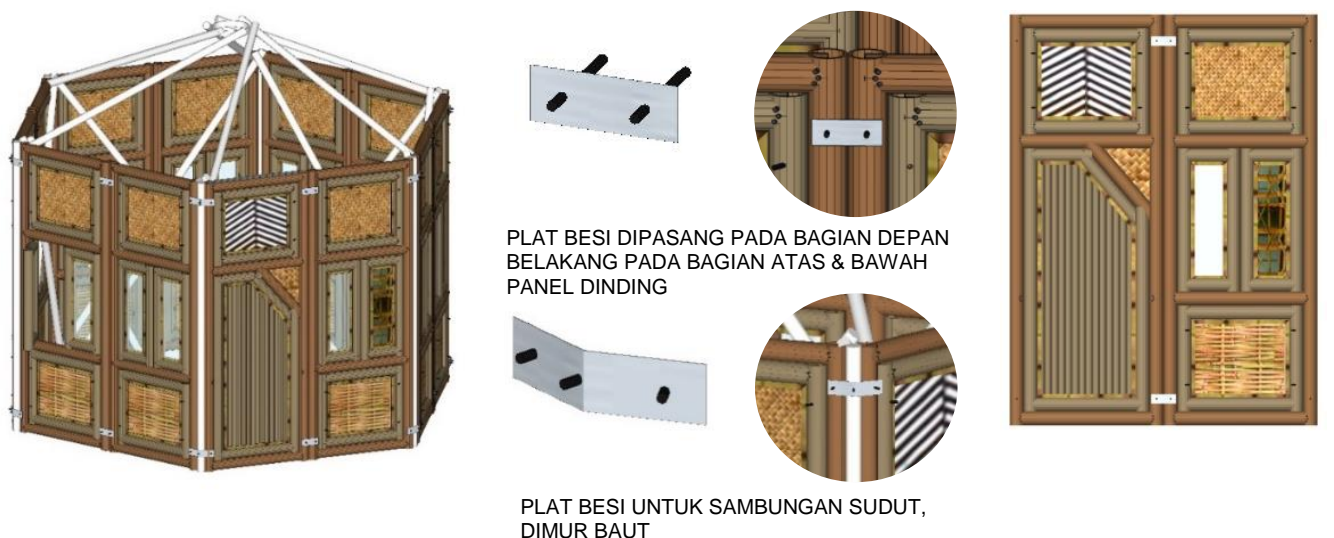

Figur 16. Aplikasi dan Sambungan Panel Dinding Bambu Knock Down pada Shelter Bambu Sumber: Dokumentasi Pribadi

\section{Keteknikan Dinding Kabula Kabale}

Ukuran BAKK dapat disesuaikan besaran panel dinding bambu knock down. Sebagai contoh, ukuran BAKK disesuaikan menjadi 4.30 x 3.80 meter. Panel dinding bambu knock down pada BAKK juga menggunakan sistem sambungan yang sama dengan sambungan pada Shelter Bambu, yakni menggunakan plat besi yang dimur baut sebagai sambungan ke struktur bangunan dan sambungan antar panel dinding bambu knock down. Panel dinding diletakkan diantara struktur bambu sehingga struktur bambu mengapit dinding. Sebelum memasang panel dinding bambu knock down, diperlukan penambahan pinjakan panel dinding yang terbuat dari bata dengan ketinggian sama dengan pedestal kolom.

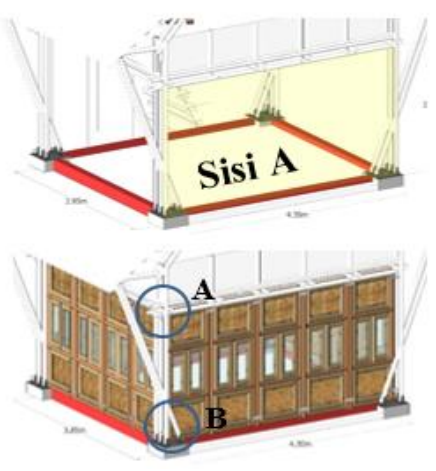

Figur 17. Sambungan Panel Dinding ke Struktur pada sisi A
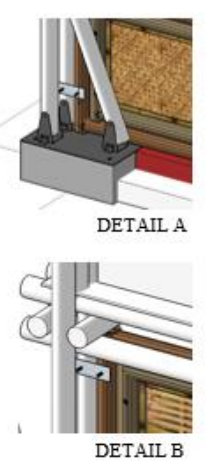

Figur 18. Sambungan Panel Dinding ke Struktur pada sisi $\mathrm{B}$

\subsection{KESIMPULAN}

Pada pembahasan pada subbab ini dapat disimpulkan bahwa proses pengerjaan panel dinding bambu knock down akan lebih efektif apabila pembuatan komponen-komponennya dapat dikerjakan individual hingga tuntas tanpa harus mengoper pekerjaan perbagian sehingga tidak menunggu proses kerja orang lain. Varian pengisi yang beragam namun ukuran modul yang sama memungkinkan pengguna untuk memilih sendiri kebutuhan dinding dan hasil dinding pada tiap-tiap bangunan juga menjadi beragam.

\section{KESIMPULAN}

Aspek yang perlu diperhatikan dalam panel dinding bambu knock down adalah bentuk, fungsi dan konteks, serta keteknikan. Bentuk meliputi material yang digunakan, modul dimensi 
dasar, berat dinding, dan kemampuan untuk dapat memodifikasi ulang dinding. Fungsi dan Konteks meliputi privasi ruang, ketahanan, dan perilaku dinding terhadap angin, panas matahari, pencahayaan, serta hujan. Keteknikan meliputi cara pengolahan bambu menjadi panel dinding, sistem sambungan, dan mampu dikerjakan secara massal oleh orang banyak.

Dari analisis komparasi dari dinding bambu pada Blooming Bamboo Home dan Soe Ker Tie House, maka dapat varian panel dinding bambu knock down yang efisien untuk digunakan. Pengelompokkan panel dinding bambu knock down dikelompokkan berdasar derajat keterbukaan dinding. Varian panel dinding bambu knock down tersebut adalah bambu bilah vertikal dan anyaman bambu bilik sebagai dinding masif, anyaman bambu dan bambu bilah modifikasi I sebagai dinding semi terbuka, bambu bilah modifikasi II dan polikatbonat sebagai dinding terbuka.Sistem sambungan yang paling tepat digunakan pada panel dinding bambu knock down adalah sambungan sekrup gypsum untuk sambungan bingkai panel dinding bambu, mur baut dan plat besi untuk sambungan panel dinding bambu knock down dengan struktur dan sambungan antar panel dinding. Pemilihan sistem sambungan didasarkan pada kemudahan dalam pengapikasian namun mampu menghasilkan sambungan yang kaku.

\section{DAFTAR PUSTAKA}

Ching, Francis D.K. (2008). Arsitektur: Bentuk, Ruang, Dan Tatanan Edisi Ketiga. Jakarta: Erlangga. Frick, Heinz. (2004). Ilmu Konstruksi Bangunan Bambu: Pengantar Konstruksi Bambu. Yogyakarta: Kanisius.

Hardin, M. (1996). The build/design workshop. Proceedings of 84th ACSA Annual Meeting, 1996.

Hatch, C. R. (1984). The scope of social architecture. NewYork: Van Nostrand Reinhold.

Husri, Zafuan., Sabrizaa, Mohd., \& Said, Suzanna. (2015). Bamboo Modular System (BMS) for New Eco Architecture. Malaysia: Education Research.

Pawar, Prof. Satish. (2014). Bamboo in Construction Technology. India : Research Publication.

Lera, S.G. (1980). "Designer's Values and The Evaluation of Designs" Dept Design Research, R.C.A., Unpub PhD Thesis.

Lobovikov, Dr. Maxim. \& Paudel, Shyam K. (2010). INBAR'sBamboo Housing Experiences. A Growing Sub-programme in INBAR.

Sudira, Bernadette,. (2016). Eksplorasi Konstruksi Bambu dengan Sistem Deployable. Skripsi tidak diterbitkan. Bandung: Universitas Katolik Parahyangan.

Yoshikawa, Isao., (2009). Bamboo Fences. Jepang: Architectural Press. 